\title{
Growing Demand for High-Quality Seafood Products and Production Systems in Aquaculture
}

\author{
Karthik Ramachandran* \\ Aquaculture Division, Guybro Chemical Private Limited, India
}

Submission: May 25, 2017; Published: June 30, 2017

*Corresponding author: Karthik an, Aquaculture Division, Guybro Chemical Pvt Ltd, Mumbai, India, Email: karthik1990vlr@gmail.com

\section{Short Communication}

Aquaculture production has grown enormously in recent years worldwide especially in Asia due to their high economic value and export. Aquaculture is the fastest growing food production sector in the world, providing almost half of the global fish/shrimp supply. Global fish and shrimp production by 2030 , it is estimated that aquaculture production will grow by $40 \%$ to satisfy global fish and shrimp demand. Shrimp and fishes are rich in proteins, vitamins, omega 3 fatty acids, selenium and essential minerals and is recommended for the maintenance of strong body and healthy bones. With increasing population and health awareness the demand for high quality fish and shrimp is increasing. Nowadays, shrimps/fishes are infected by numerous pathogenic microbes which caused high mortality. The excess feed and fecal matter in grow out ponds accumulating in the impoundments may result in bacterial decomposition of organic matter in the sedimentand produce excess of toxic compounds like ammonia and also pollute the environment. Very limited research has been carried out on the culture, growth performance and disease management in aquaculture using beneficial microbes. Although vaccines, medicated feeds and immunostimulants are effective in combating some pathogens in other meat-producing programmes, they are either unavailable to shrimp farmers or their efficacy is unproven. Various pond management strategies like stocking of high-health seed, reducing water exchange rate, and screening influent water have been employed to mitigate the risk of disease outbreak. To meet the growing demand for high-quality shrimp products, novel production systems must be designed to minimize the introduction and spread of pathogenic agents, as well as to protect coastal resources. Biosecure zeroexchange systems represent an emerging technology that provides a high degree of pathogen exclusion with minimal water exchange. An important ramification associated with reduced or zero water exchange is the increased importance of in situ microorganisms both in regulating biogeochemical cycles within the culture environment and in directly affecting shrimp growth and survival.
Biosecurity can be defined as the sum of all procedures in place to protect living organisms from contracting, carrying and spreading diseases and other undesirable health conditions. When designing a biosecure production facility, it is important to identify all known and potential disease vectors. For shrimp viruses, one of the most important vectors is the seed. The use of shrimp specific pathogen free (SPF) seeds of high health sources is highly recommended. Aquaculture uses resources from and interacts with the environment. Many aquaculture operations generate metabolic waste products (e.g., faeces, ammonia, uneaten food etc.) that are released into the receiving waters. In some cases, the organic particulate waste will accumulate on the seabed in the immediate vicinity of the farm, while soluble waste will eventually end up in the receiving waters. Organic enrichment of the benthic ecosystem may result in formation of anoxic conditions. Under extreme cases, reduction in macrofauna biomass, abundance and species composition may also follow. In semi-intensive and intensive pond systems, sometime up to $40 \%$ of pond volume is exchanged daily. Often on large farms, water exchange is based on a set schedule, with occasional emergency flushes, rather than as an ongoing response to changing pond conditions.

Disease outbreak is being increasingly recognized as a significant constraint on aquaculture production and trade, affecting the economic development of the sector in many countries. It is the limiting factor in the shrimp culture subsector. So far, conventional approaches, such as the use of disinfectants and antimicrobial drugs have had limited success in the prevention or cure of aquatic disease. Furthermore, there is a growing concern about the use and, particularly, the abuse of anti-microbial drugs not only in human medicine and agriculture but also in aquaculture. The massive use of antimicrobials for disease control and growth promotion in animals increases the selective pressure exerted on the microbial world and encourages the natural emergence of bacterial resistance. Not only can 
resistant bacteria proliferate after an antibiotic has killed off the other bacteria, but also they can transfer their resistance genes to other bacteria that have never been exposed to the antibiotic. Frequently, pond flushing removes plankton, bacteria and natural productivity that could have otherwise benefited the pond water quality and the cultured organisms. Reducing water exchange is feasible without negatively affecting the culture environment. High shrimp yield can be produced without water exchange. In semi-intensive and extensive farming, all or part of the waste is recycled into micro-algae production. A normal bacterial composition may also keep the pond healthy and reduce risks for rapid spread of pathogenic microbes. A sterile pond may increase disease risks substantially, since any microbe that enters the system might easily take over. To reduce the risk, experiment is now made to introduce probiotics that is "friendly microbes", in the farming environment to suppress and out competitive pathogenic ones.

Considering the recent success of these alternative approaches the Food and Agriculture Organization of the United Nations defined the development of affordable yet efficient vaccines, the use of immuno-modulators and nonspecific immune enhancers and the use of probiotics and bioaugmentation for the improvement of aquatic environmental

This work is licensed under Creative Commons Attribution 4.0 Licens DOI: 10.19080/OFOAJ.2017.03.555614 quality as major areas for further research disease control in aquaculture. Microbial probiotics is a term, which in aquaculture, usually refers to a bacterial supplement of a single or mixed culture of selected bacteria. These bacteria are added to aquaculture production systems in order to modify or manipulate the microbial communities in the water and sediment to reduce or eliminate selected pathogenic species of microorganisms, and generally, to improve growth and survival of the targeted cultured aquatic species. Additionally, according to the demonstrations of manufacturers and distributors of probiotics, the products improve water quality and lower the level of the organic sludge in the aquaculture facility. The newest attempt to improve water quality in aquaculture is the application of probiotics and/or enzymes to ponds. This approach of biotechnology is known as bioremediation, which involves manipulation of microorganisms in ponds to enhance mineralization of organic matter and get rid of undesirable waste compounds. Hence, the extrapolation of beneficial microbes/enzymes as feed and/or water probiotics in shrimp culture will definitely prevent the aquaculture ponds from undergoing organic matter accumulation, ammonification, eutrophication and prevent the environment from pollution and also control the microbial diseases to the shrimps and enhance the productivity of the farms to the benefit of local economies in an ecofriendly ambience without antibiotics.

\section{Your next submission with Juniper Publishers will reach you the below assets}

- Quality Editorial service

- Swift Peer Review

- Reprints availability

- E-prints Service

- Manuscript Podcast for convenient understanding

- Global attainment for your research

- Manuscript accessibility in different formats

( Pdf, E-pub, Full Text, Audio)

- Unceasing customer service

Track the below URL for one-step submission https://juniperpublishers.com/online-submission.php 